Arq. Bras. Med. Vet. Zootec., v.69, n.3, p.623-626, 2017

\title{
Intestinal intussusception secondary to enteritis caused by Pythium insidiosum in a bitch: case report
}

\author{
[Intussuscepção intestinal secundária à enterite causada por \\ Pythium insidiosum em uma cadela: relato de caso] \\ M.O. Firmino, M.T.S. Frade, R.C. Alves, L.Â. Maia, R.G. Olinda, R.G. Ximenes, \\ A.P. Souza, A.F.M. Dantas \\ Programa de pós-graduação - Universidade Federal de Campina Grande - Patos, PB
}

\begin{abstract}
We report a case of intestinal intussusception secondary to enteritis caused by Pythium insidiosum infection in a 1-year-old mixed breed bitch that died after a 30-day history of bloody diarrhea, anorexia, weight loss, listlessness, dehydration, and pale mucous membranes. Necropsy revealed two areas of intussusception, one jejunum-jejunal and one ileum-cecum-colic. The first intussusception showed slight congestion of the intestinal loop, which was resolved by manual traction, while the second intussusception exhibited thickening, irregular yellow spots, and transmural congestion. Histologically, the jejunum-jejunal segment had ischemic lesions secondary and ileum-cecum-colic intussusception there was also necrotizing, pyogranulomatous enteritis associated with negative images of intralesional fungal hyphae that were well visualized by silver impregnation. Immunohistochemistry identified the hyphae as Pythium insidiosum. The diagnosis was made based on the histological changes and confirmed by immunohistochemistry. We can conclude that enteritis by $P$. insidiosum in dogs can occasionally cause intestinal intussusception and result in acute death.
\end{abstract}

Keyword: Pythiosis, pyogranulomatous enteritis, Immunohistochemistry, intestinal intussusception, Pythium insidiosum

\section{RESUMO}

Relata-se um caso de intussuscepção intestinal secundária à enterite causada por Pythium insidiosusm em uma cadela, sem raça definida, com um ano de idade, que morreu após apresentar 30 dias de diarreia sanguinolenta, anorexia, perda de peso, apatia, desidratação e mucosas pálidas. Na necropsia verificaram-se duas áreas de intussuscepções, sendo uma jejuno-jejunal e outra íleo-ceco-cólica. Na primeira havia discreta congestão, que foi desfeita pela tração manual, e na segunda observou-se espessamento segmentar, focos amarelados irregulares e congestão transmural do intestino. Microscopicamente, no segmento jejuno-jejunal observaram-se moderadas lesões isquêmicas secundárias à intussuscepção, e no segmento íleo-ceco-cólica verificou-se enterite piogranulomatosa e necrosante, segmentar, associada a imagens negativas de hifas intralesionais, impregnadas pela prata. Pela imuno-histoquímica, as hifas foram imunomarcadas para Pythium insidiosum. $O$ diagnóstico foi realizado com base nas características microscópicas das lesões $e$ morfotintoriais das hifas e foi confirmado pela imuno-histoquímica. De acordo com esses dados, é possível concluir que a infecção intestinal por P. insidiosum em cães pode causar intussuscepção e morte.

Palavras-chave: pitiose, enterite piogranulomatosa, imuno-histoquímica, intussuscepção intestinal, Pythium insidiosum

\section{INTRODUCTION}

Intussusception is an invagination and entrapment of an intestinal segment into an adjacent segment. It results from changes in peristalsis and has been observed in various animal species, including humans (Queiroz et al.,

Recebido em 8 de julho de 2016

Aceito em 28 de setembro de 2016

E-mail: millena_deoliveira@yahoo.com.br
2015). The most commun causes of intestinal intussusception reported in animals are infectious gastroenteritis and neoplasm. (Rallis et al., 2000; Gelberg, 2013). Neoplasia, and canine parvovirus- 2 infection has been described as one of the main causes of intussusception in dogs (Rallis et al., 2000), followed by foreign bodies, nematode parasites and intestinal inflammation (Gelberg, 2013). 
Pythiosis is caused by Pythium insidiosum, an aquatic oomycete the kingdom Stramenopila, and affects several species of domestic animals, wildlife and humans (Rakich et al., 2005; Martins et al., 2012). The equine species is the most affected, followed by canines. The occurrence of disease is related to animal contact with contaminated water by mobile zoospores, which is the infective form of the agent (Martins et al., 2012).

Pyogranulomatous gastroenteritis caused by Pythium insidiosum has been described in horses (Bezerra Júnior et al., 2010), sheep (Pessoa et al., 2012), cats (Rakich et al., 2005) and dogs (Galiza et al., 2014; Fujimori et al., 2016). However, we did not find any reports of enteric pythiosis resulting in intestinal intussusception in Veterinary Medicine literature. Thus, this case study aims to report a case of intestinal intussusception secondary to necrotizing pyogranulomatous enteritis caused by $P$. insidiosum in a bitch.

\section{CASE REPORT}

A 1-year-old, mixed breed bitch was admitted to the veterinary hospital with a 30-day history of bloody diarrhea, anorexia, apathy, weight loss, dehydration, and anemia. It had previously received antibiotic therapy. The animal was raised in a neighborhood in the town of Tabira$\mathrm{PE}$ and, according to the owner, had daily access to the street and occasionally the countryside, which may have favored contact with water or soil contaminated by agent. The bitch died shortly after admission and was submitted to necropsy.

Grossly, a focal area of intussusception was found in the jejunum. The intussusceptum measured $7 \mathrm{~cm}$ and was easily broken by manual traction. The bowel were red, serous slightly granular, and mucosa covered diffuse by fibrin. There was also an ileum-cecum-colic intussusception where the intussusception, comprising the cecum and ileum, measured $5 \mathrm{~cm}$ and was not easily undone by manual traction.
There were multifocal coalescing dark red areas in serous. This segment had red liquid within the lumen the mucosa was diffusely dark red with multifocal areas of ulceration and multifocal coalescing yellow areas that were slightly elevated (Figure 1A and 1B). On cross-section of the ileum and cecum, there was transmural thickening and multifocal, yellow, irregular areas ranging from 0.1 to $0.3 \mathrm{~cm}$ in diameter (Figure 1C).

Tissues were collected, fixed in $10 \%$ buffered formalin, processd for histology and stained with hematoxylin and eosin (HE). Histologically, the jejunum-jejunal intussusception exhibited pronounced coagulative necrosis, hemorrhage, and congestion, associated with a mild inflammatory infiltrate composed of macrophages, plasma cells, and neutrophils. The ileum-cecum-colic intussusception exhibited diffuse, marked granulomatous and necrotizing enteritis, characterized by multifocal areas of coalescent necrosis, surrounded by epithelioid macrophages, multinucleated giant cells, and neutrophils, with peripheral fibrosis extending which stretched from the mucous membrane into the muscular layer. In the areas of necrosis and in the cytoplasm of multinucleated giant cells and macrophages, there were tubuliform structures (Figure 1D).

Fungal hyphae were positive on Grocott methenamine silver (GMS) stained sections. Hyphae were parallel walls, rarely septate, measuring approximately $2-8 \mu \mathrm{m}$ (Figure 1E). They were negative on periodic acid-Schiff (PAS) reaction. Diagnostic confirmation was achieved by immunohistochemistry (IHC). The IHC protocol was performed according to Martins et al. (2012) using a polyclonal antibody (anti-P.insidiosum) produced in rabbits (Gabriel et al. 2008). Briefly, we used the primary antibody at a dilution of 1:800, detected by a streptavidin-peroxidase technique and the chromogen 3.3'-diaminobenzidine (DAB), which revealed strong immunostaining on the wall and cytoplasm of hyphae (Figure 1F). 

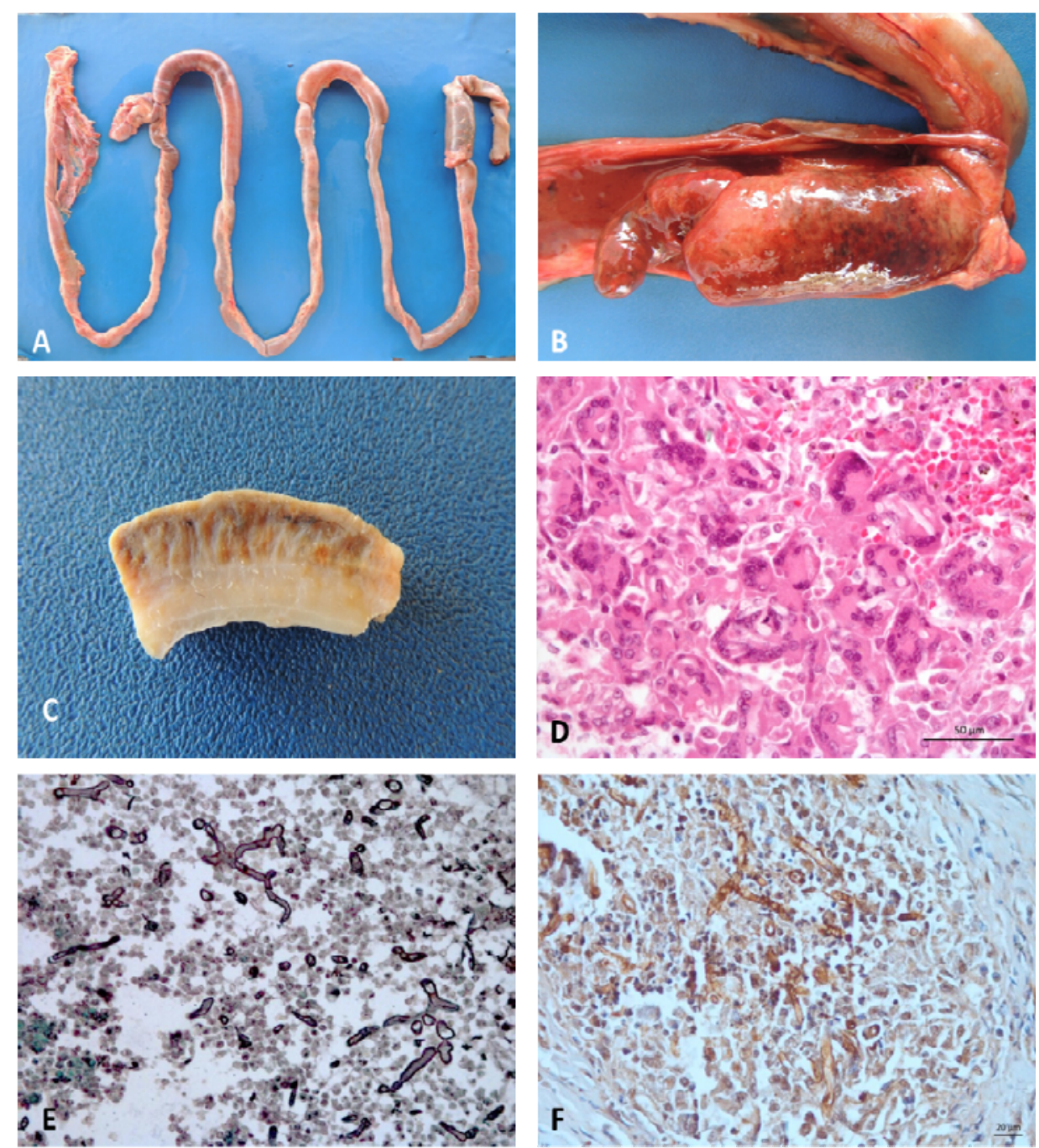

Figure 1. Intussusception secondary to intestinal pythiosis in a bitch. A) Intestine demonstrating areas of intussusception, both jejunum-jejunal and ileum-cecum-colic. B) The observed intussusception of the ileum and cecum with diffusely dark red and irregular mucosa. C) Cross-section of the ileum, demonstrating transmural thickening and multifocal yellow irregular areas. D) Multinucleated giant cells with non-stained cytoplasmic hyphae. HE. Obj. 40x. E) Hyphae are positive on silver Grocott methenamine silver. GMS. 20x. F) Hyphae have strong immunostaining, Streptavidin-peroxidase and 3.3'-diaminobenzidine (DAB). Obj. 20x.

\section{DISCUSSION}

The diagnosis of intestinal intussusception caused by enteritis due to $P$. insidiosum infection in this dog was based on the histological characteristics of the lesions and confirmed by IHC. In the literature, cases of intestinal pythiosis causing intussusception in dogs have not been documented.
It is hypothesized that the infection by $P$. insidiosum has induced severe inflammation with consequent distention of the bowel wall, causing dysfunction of the motility and leading to intussusception. It is likely that the mild chronic inflammation seen in the ileum-cecum-colic segment caused local atony (Oliveira-Barros e Matera, 2009) and stimulated peristalsis and the subsequent invagination of the injured intestinal segment. The jejunal intussusception possibly occurred as a result of the changes in peristalsis 
promoted by the injured ileum-cecum-colic segment. Gastrointestinal pythiosis in dogs is typically characterized by a marked mural thickening of the affected segments of stomach or intestine (Galiza et al., 2014; Fujimori et al., 2016), and rarely the esophagus or pharynx. These cases are usually fatal because diagnosis is typically made when lesions have reached an advanced stage and surgical excision is no longer feasible (Hensel et al., 2003).

The main causes of intestinal intussusception in puppies include parasitic diseases, linear foreign bodies, and infectious enteritis with viral origin (Oliveira-Barros e Matera 2009; Gelberg, 2013). Other cases of intussusception have been attributed to idiopathic infectious enteritis (Rallis et al., 2000; Gelberg, 2013), previous surgical procedures, and intestinal neoplasia (Gelberg, 2013). No evidence of any other disease was found in this dog. Therefore, we conclude that enteritis due to by $P$. insidiosum infection can occasionally cause intussusception and death of affected dogs.

\section{REFERENCES}

BERTOY, RW. Megacolon in the cat. Vet. Clin. N. Am.: Small Anim. Pract., v.32, p.901-915, 2002.

BEZERRA-JÚNIOR, P.S.; PEDROSO, P.M.O.; PAVARINI, S.P. et al. Equine intestinal pythiosis in southern Brazil. Arq. Bras. Med. Vet. Zootec., v.62, p.481-483, 2010.

FUJIMORI, M.; LOPES, E.R.; LIMA, S.R. et al. Pythium insidiosum colitis in a dog: treatment and clinical outcome. Ciênc. Rural, v.46, p.526$529,2016$.

GABRIEL, A.L.; KOMMERS, G.D.; TROST, M.E. et al. Surto de pitiose cutânea em bovinos. Pesqui. Vet. Bras., v.28, p.583-587, 2008.
GALIZA, G.J.N.; SILVA, T.M.; CAPRIOLI, R.A. et al. Ocorrência de micoses e pitiose em animais domésticos: 230 casos. Pesqui. Vet. Bras., v.34, p.224-232, 2014.

GELBERG, H.B. Sistema alimentar, peritônio, omento, mesentério e cavidade peritoneal, In: MCGAVIN, M.D.; ZACHARY, J.F. Bases da patologia veterinária. 5.ed. Rio de Janeiro: Elsevier, 2013. cap.7, p.365-366.

HENSEL, P.; GREENE, C.E.; MEDLEAU, L. et al. Immunotherapy for treatment of multicentric cutaneous Pythiosis in a dog. Am. Vet. Med. Assoc., v.223, p.215-218, 2003.

MARTINS, T.B.; KOMMERS, G.D.; TROST, M.E. et al. A comparative study of the histopathology and immunohistochemistry of pythiosis in horses, dogs and cattle. J. Comp. Pathol., v.146, p.122-131, 2012.

OLIVEIRA-BARROS, L.M.; MATERA, J.M. Intussuscepção em cães: revisão de literatura. Rev. Acad. Ciênc. Agrár. Ambient., v.7, p.265272, 2009.

PESSOA, C.R.; RIET-CORREA, F.; PIMENTEL, L.A. et al. Pythiosis of the digestive tract in sheep. J. Vet. Diagn. Invest., v.24, p.1133-1136, 2012.

QUEIROZ, R.M.; BOTTER, L.A.; GOMES, M.P.; OLIVEIRA, R.G.G. Enteroenteric intussusception in an adult caused by an ileal angiomyolipoma. Radiol. Bras., v.48, p.333-340, 2015.

RAKICH, P.M.; GROOTERS, A.M.; TANG, K.N. Gastrointestinal pythiosis in two cats. J. Vet. Diagn. Invest. v.17, p.262-269, 2005.

RALLIS, T.S.; PAPAZOGLOU, L.G.; ADAMAMA-MORAITOU, K.K.; PRASSINOS, N.N. Acute enteritis or gastroenteritis in young dogs as a predisposing factor for intestinal intussusception: a retrospective study. J. Vet. Med., v.47, p.507- 511, 2000. 